\title{
Uboczne produkty spalania jako odpady niebezpieczne w świetle nowych regulacji prawnych
}

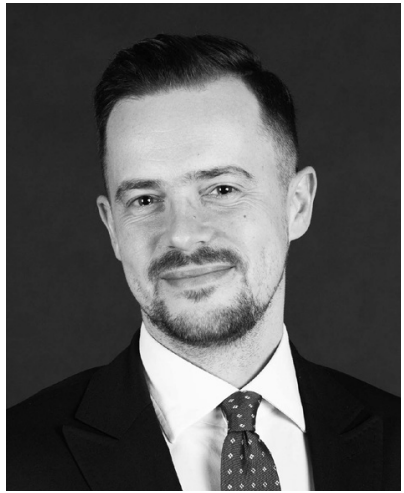

\section{Artur Modrzejewski}

Adiunkt w Katedrze Prawa Administracyjnego na Wydziale Prawa Uniwersytetu $w$ Bialymstoku, etatowy członek Samorządowego Kolegium Odwoławczego w Białymstoku. Jego zainteresowania badawcze koncentrują się wokót prawa odpadowego.

$\bowtie$ a.modrzejewski@uwb.edu.pl https://orcid.org/oooo-0002-3849-4208

\section{By-products from the Combustion as Hazardous Waste New Legal Solution}

\begin{abstract}
The article is an attempt to analyse legal solution in the area of hazardous waste (ash, slags), especially the way of changing of waste classification and the possibility of using them as side products.
\end{abstract}

Słowa kluczowe: odpady niebezpieczne, żużle, popioły, produkt uboczny Key words: hazardous waste (ash, slags), waste classification, by-products

https://doi.org/10.32082/fp.v2i52.248

\section{Wprowadzenie}

Zasadą jest, że odpady niebezpieczne wymagają szczególnej regulacji i ustanowienia nadzoru w zakresie postępowania z nimi ${ }^{1}$. Tym bardziej wyważone i ostrożne powinny być działania podejmowane przez ustawodawcę odnoszące się do tej właśnie kategorii odpadów. Ustawa z dnia 24 listopada 2017 r. o zmianie ustawy o odpadach oraz niektórych innych ustaw ${ }^{2}$ wprowadziła

1 P. Korzeniowski, Model prawny systemu gospodarki odpadami. Studium administracyjno-prawne, Łódź 2014, s. 246

2 Ustawa z dnia 24 listopada $2017 \mathrm{r}$. o zmianie ustawy o odpadach oraz zmiany w klasyfikacji odpadów niebezpiecznych. Dotychczasowe przepisy określające właściwości, które powodują, że odpady są odpadami niebezpiecznymi, oraz warunki uznania odpadów za niebezpieczne zostały zastąpione Rozporządzeniem (UE) nr 1357/2014 z dnia 18 grudnia 2014 r. ${ }^{3}$ oraz Rozporządzeniem (UE) nr 2017/997 z dnia 8 czerwca

niektórych innych ustaw, Dz.U. 2017, poz. 2422.

3 Rozporządzenie Komisji (UE) nr 1357/2014 z dnia 18 grudnia 2014 r. zastępujące załącznik III do dyrektywy Parlamentu Europejskiego i Rady 2008/98/WE w sprawie odpadów oraz uchylającej niektóre 
2017 r. w odniesieniu do odpadów posiadających właściwości ekotoksyczne 4 .

W Rozporządzeniu (UE) nr 1357/2014 załącznik III określa właściwości odpadów, które czynią z nich odpady niebezpieczne. Wyróżniono 15 grup, którym przydzielono różne kody. Zmienione zostały definicje właściwości niebezpiecznych oraz kody właściwości od H 1 do H 15, odpowiednio na kody HP 1 do HP 15. Kolejną zmianą jest dostosowanie nazw właściwości H 5 („szkodliwe”) i H 6 („toksyczne”) do nowych klas i kategorii, tj. HP 5 [„Działanie toksyczne na narządy docelowe (STOT) lub zagrożenie spowodowane aspiracją] oraz HP 6 („Ostra toksyczność”). Nową nazwę zyskały również kody H 12 - „odpady, które w kontakcie z wodą, powietrzem lub kwasem uwalniają toksyczne lub bardzo toksyczne gazy” oraz H 15 - „odpady, które po zakończeniu procesu unieszkodliwiania mogą w dowolny sposób wydzielić inną substancję, np. w formie odcieku, która ma którąkolwiek spośród cech wymienionych powyżej”. Obecnie, aby zapewnić spójność z innymi nazwami, brzmią one odpowiednio: HP 12 („Uwolnienie gazów o ostrej toksyczności”) oraz HP 15 („odpady mogące wykazywać niebezpieczne właściwości wymienione powyżej, które nie były bezpośrednio widoczne w odpadach pierwotnych").

W Rozporządzeniu (UE) nr 1357/2014 nie została zmieniona definicja właściwości HP 14, ponieważ niezbędne były do tego dodatkowe badania. Po zakończeniu badań zalecenia dotyczące oceny niebezpiecznej właściwości zostały uwzględnione w drugim rozporządzeniu UE - nr 2017/997. Odpady traktowane jako ekotoksyczne według tego dokumentu są odpadami zubożającymi warstwę ozonową oraz odpadami zawierającymi przynajmniej jedną substancję stwarzającą zagrożenie dla środowiska wodnego.

Rozporządzenia unijne zastępują Załącznik nr 3 u.o. Zgodnie z treścią art. 2 Rozporządzenia (UE) nr 1357/2014 - rozporządzenie stosuje się od dnia

dyrektywy, Dz.Urz. UE L 365 z 19.12.2014, s. 89, z późn. zm. [dalej: Rozporządzenie (UE) nr 1357/2014].

4 Rozporządzenie Rady (UE) 2017/997 z dnia 8 czerwca 2017 r. zmieniające załącznik III do dyrektywy Parlamentu Europejskiego i Rady 2008/98/WE w odniesieniu do niebezpiecznej właściwości HP 14 „Ekotoksyczne”, Dz.Urz. UE L 150 z 14.06.2017, s. 1 [dalej: Rozporządzenie (UE) 2017/997].
1 czerwca 2015 r. Zgodnie zaś z treścią art. 2 Rozporządzenia (UE) 2017/997 - rozporządzenie stosuje się od dnia 5 lipca 2018 r. Oznacza to, że rozporządzenie stosowane jest bezpośrednio nawet pomimo ewentualnego braku polskich przepisów regulujących kwestie określone w rozporządzeniu.

W praktyce oznacza to, że popioły i żużle stanowiące tzw. uboczne produkty spalania (w skrócie „UPS”), po przeprowadzeniu stosownych badań zgodnie z wymogami aktów unijnych, mogą z dnia na dzień stać się odpadami niebezpiecznymi, przez co utrudnione będzie dalsze postępowanie $\mathrm{z}$ nimi.

Jak znaczny jest to problem, obrazuje statystyka zawarta w uzasadnieniu Ustawy o zmianie ustawy o odpadach. Według danych GUS w Polsce w 2015 r. wytworzono $142 \mathrm{mln}$ ton odpadów, z czego $8 \%$ stanowiły odpady komunalne (11 mln ton). Ilość wytworzonych w Polsce odpadów (z wyłączeniem odpadów komunalnych) od $2000 \mathrm{r}$. kształtowała się w granicach 110-130 mln ton. Wytworzenie $131 \mathrm{mln}$ ton odpadów innych niż komunalne w roku 2015 oznacza spadek o 0,2\% w stosunku do roku poprzedniego. Głównym źródłem odpadów w 2015 r. były, podobnie jak w latach poprzednich: górnictwo i wydobywanie (ok. 53\% ilości wytworzonych odpadów ogółem), przetwórstwo przemysłowe (21\%) oraz wytwarzanie i zaopatrywanie w energię elektryczną $(16 \%)^{5}$.

Dane te oznaczają, że $20 \mathrm{mln}$ ton popiołów i żużli produkowanych w skali jednego roku może stać się odpadem niebezpiecznym. Efektem będzie brak możliwości wykorzystania UPS w uznanych i sprawdzonych zastosowaniach, jako np. domieszka do cementu czy też w konstrukcjach drogowych. Ponadto zaistnieje ryzyko uznania składowisk odpadów paleniskowych za składowiska odpadów niebezpiecznych. Przy gospodarce opartej na węglu istnieje znaczące niebezpieczeństwo wzrostu cen wytwarzania energii elektrycznej i ciepła ${ }^{6}$.

Celem niniejszej publikacji jest analiza rozwiązań prawnych określających sposób postępowania

5 Druk nr 2014 z dnia 9 listopada 2017 r., o zmianie ustawy o odpadach z projektami aktów wykonawczych, s. 8, https:// www.sejm.gov.pl/Sejm8.nsf/druk.xsp?nr=2014 (dostęp 13.11.2019)

6 Tamże. 
z odpadami niebezpiecznymi - w tym w szczególności odnoszącymi się do sposobu zmiany klasyfikacji tych odpadów oraz możliwości wykorzystania ich jako produktów ubocznych. Pomimo tego, że doktryna prawa kającemu z art. 7 i art. 8 u.o. ${ }^{9} \mathrm{~W}$ takim przypadku to na posiadaczu odpadów spoczywa ciężar odpowiedzialności w zakresie prawidłowej klasyfikacji odpadów. Charakter odpadu określony jest na podstawie

\section{Warto poważnie podjąć kwestię, jak prawo} określa sposób postępowania $\mathrm{z}$ odpadami niebezpiecznymi - w tym w szczególności sposobu zmiany klasyfikacji tych odpadów oraz możliwość wykorzystania ich jako produktów ubocznych.

ochrony środowiska postępowanie z odpadami niebezpiecznymi zalicza jedynie do funkcji pomocniczych gospodarki odpadami ${ }^{7}$, to skala problemu nakazuje podjąć poniższe rozważania.

\section{Zmiana statusu prawnego popiołów i żużli}

Katalog odpadów określony Rozporządzeniem w sprawie katalogu odpadó ${ }^{8}$ jest tak sformułowany, że często dla tych samych rodzajów odpadów przewiduje występowanie dwóch kodów odpadów, tzw. zwierciadlanych: innych niż niebezpieczne i niebezpiecznych. Tego rodzaju sytuacja ma miejsce w przypadku żużli i popiołów paleniskowych, które mogą być klasyfikowane pod kodem 190112 (żużle i popioły paleniskowe inne niż wymienione w 1901 11) bądź pod kodem $1901111^{*}$ - jeśli zawierają substancje niebezpieczne.

W przypadku gdy dany podmiot klasyfikuje odpady jako inne niż niebezpieczne, pod kodem odpadów posiadającym swój odpowiednik z gwiazdką (tzw. „kod lustrzany”), nie podlega on obowiązkowi wyni-

7 P. Korzeniowski, Instrumenty prawne reglamentacji w gospodarce odpadami, „Przegląd Prawa Ochrony Środowiska” 2014, t. 3, s. 18 .

8 Rozporządzenie Ministra Środowiska z dnia 9 grudnia 2014 r. w sprawie katalogu odpadów, Dz.U. 2014, poz. 1923 (dalej: Rozporządzenie w sprawie katalogu odpadów). stosownych badań przeprowadzonych przez akredytowane laboratorium i wskazany jest m.in. w charakterystyce odpadu.

W świetle obecnie obowiązujących przepisów posiadacz odpadów może dokonać zmiany klasyfikacji odpadów niebezpiecznych na odpady inne niż niebezpieczne, jeżeli wykaże, że nie posiadają one właściwości powodujących, że odpady są odpadami niebezpiecznymi, określonych w Rozporządzeniu (UE) nr 1357/2014 i w Rozporządzeniu (UE) 2017/997, a w przypadku odpadów posiadających właściwości zakaźne - również że nie spełniają one warunków uznania odpadów za posiadające właściwości zakaźne określonych w przepisach wydanych na podstawie art. 3 ust. 5 u.o.

Badania odpadów należy przeprowadzać zgodnie z Wytycznymi technicznymi Komisji w sprawie klasyfikacji odpadów ${ }^{10}$, który to dokument w obliczu braku odpowiednich polskich aktów wykonawczych urasta

9 Ustawa z dnia 14 grudnia 2012 r. o odpadach, t.j. Dz.U. 2018, poz. 992 (dalej: u.o.).

10 Informacje Instytucji, Organów i Jednostek Organizacyjnych Unii Europejskiej Komisja Europejska, Zawiadomienie Komisji dotyczące wytycznych technicznych w sprawie klasyfikacji odpadów z dnia 9 kwietnia 2018 r., 2018/C 124/01 (dalej: Wytyczne techniczne Komisji w sprawie klasyfikacji odpadów). 
do rangi jedynych przepisów określających techniczne uwarunkowania przeprowadzenia stosownych badań.

Ustawa o odpadach nie przewiduje wprost trybu zmiany klasyfikacji odpadów innych niż niebezpieczne na odpady niebezpieczne. Reguluje ona w sposób szczegółowy jedynie procedurę odwrotną (przepisy rozdz. 3). Jak wskazano powyżej, niektóre odpady można jednak zaklasyfikować w ewidencji zarówno jako niebezpieczne, jak i inne niż niebezpieczne. Jeżeli nowa klasyfikacja wytwarzanego odpadu doprowadzi do zmiany w zakresie: niebezpieczne - inne niż niebezpieczne, to zmianie podlega także kod odpadu. niż niebezpieczne na niebezpieczne, jest obarczone ryzykiem konieczności stosowania bardziej restrykcyjnych wymogów, np. w toku ich składowania.

Zmiana przypisanego kodu odpadu może być tylko zabiegiem formalnym. Od tego momentu wytwarzający odpad będzie przekazywać go pod innym kodem, co będzie miało swoje odbicie w Kartach ewidencji odpadów, Kartach przekazania odpadów oraz Sprawozdaniach rocznych. O poprawnym wyborze kodu sytuacji decydują właściwości odpadów, a ich prawidłowa klasyfikacja - oparta na właściwościach - jest zadaniem wytwórcy odpadów.

\section{Zmiana przypisanego kodu odpadu może być tylko zabiegiem formalnym. Od tego momentu} wytwarzający odpad będzie przekazywać go pod innym kodem, co będzie miało swoje odbicie w Kartach ewidencji odpadów, Kartach przekazania odpadów oraz Sprawozdaniach rocznych.

Zmiany takiej można dokonać samodzielnie, tzn. np. na skutek przeprowadzonych badań związanych z charakterystyką odpadu; przy tym badania powinny być zgodne z Wytycznymi technicznymi Komisji w sprawie klasyfikacji odpadów. Nie podważa to faktu, iż na posiadaczu odpadów ciąży cały czas ciężar prawidłowej klasyfikacji odpadów wynikający z art. 4 w zw. z art. 6 u.o. Błędna klasyfikacja odpadów, jako innych niż niebezpieczne, może być podważona przez uprawnione do tego organy, ze wskazaniem, że odpady zakwalifikowane przez posiadacza odpadów jako odpady inne niż niebezpieczne w rzeczywistości są odpadami niebezpiecznymi ${ }^{11}$. Przekwalifikowanie samodzielnie odpadów w drugą stronę, tzn. innych

11 Ministerstwo Środowiska, Stanowisko w sprawie zmiany statusu odpadów niebezpiecznych na odpady inne niż niebezpieczne, 18 czerwca 2013 r., https://archiwum.mos.gov.
Wszczęcie procedury administracyjnej polegającej na zgłoszeniu zmiany dotyczy więc, zgodnie $\mathrm{z}$ art. 8 u.o., tylko przypadków zmiany klasyfikacji w sensie odstępstwa od rozporządzenia, niezależnie od tego, że odnosi się wyłącznie do klasyfikowania odpadów niebezpiecznych jako inne niż niebezpieczne. Nadanie odpadom innym niż niebezpieczne statusu odpadów niebezpiecznych nie jest więc możliwe wobec indywidualnego posiadacza odpadów. Musiałoby dojść do zmiany takiej kwalifikacji w przepisach rozporządzenia Ministra Środowiska.

W związku z tym należy uznać, że obowiązujące przepisy nie przewidują możliwości zmiany kwalifikacji odpadów innych niż niebezpieczne na odpady niebezpieczne drogą inną niż zmiana rozporządze-

pl/g2/big/2013_06/cc27612a0ab016a2a87112d2b0d5d6d2. pdf, (dostęp: 27.08.2018). 
nia Ministra Środowiska. Jeśli posiadacz odpadów dostrzega, iż odpady, którymi gospodarował dotąd jako nieposiadającymi właściwości niebezpiecznych, właściwości te jednak posiadają, zmienia sposób gospodarowania nimi w ramach prowadzonej gospodarki odpadami - odpowiednio do klasyfikacji, jaką przyjął $\mathrm{w}$ ramach prowadzonej gospodarki.

Zmiany, jakie przynoszą nowe zasady klasyfikacji odpadów w zakresie właściwości niebezpiecznych, mogą mieć zasadnicze znaczenie dla funkcjonowania podmiotów wytwarzających odpady. Odpad o tym odpadu (art. 24 ust. 2 u.o.: transport odpadów niebezpiecznych odbywa się z zachowaniem przepisów obowiązujących przy transporcie towarów niebezpiecznych). Wynikiem tego procesu może być powstanie obligacji przewozu odpadu w warunkach pełnego ADR. Firma w takim przypadku ma obowiązek zatrudnienia doradcy DGSA (Dangerous Goods Safety Adviser - doradca ds. bezpieczeństwa w transporcie) oraz składania rocznych sprawozdań z przewozu towarów niebezpiecznych.

Podmiot wytwarzający odpady, działający na podstawie posiadanej decyzji administracyjnej, zobo-

\section{Jeśli w wyniku przeprowadzonych badań okaże} się, że odpady powinny być klasyfikowane jako niebezpieczne, wówczas $\mathrm{w}$ dokumentacji zarządzającego instalacją i innych dokumentach, zmianie powinien ulec również kod odpadów (kod z zastosowaniem gwiazdki).

samym składzie, klasyfikowany do tej pory jako inny niż niebezpieczny, po przeprowadzeniu klasyfikacji według nowych przepisów, może być uznany za odpad niebezpieczny lub odwrotnie.

Jeśli więc w wyniku przeprowadzonych badań okaże się, że odpady powinny być klasyfikowane jako niebezpieczne, wówczas w dokumentacji zarządzającego instalacją i innych dokumentach, zmianie powinien ulec również kod odpadów (kod z zastosowaniem gwiazdki). Zmianie ulega także sposób postępowania z tymi odpadami. Konieczne może być w tym zakresie dokonanie zmiany, np. pozwolenia zintegrowanego, ze wskazaniem innych właściwości i zamiany kodu odpadu na ten z gwiazdką.

Przejście na kod odpadu niebezpiecznego generuje nową obligację - przeprowadzenie klasyfikacji $\mathrm{ADR}^{12}$

12 L'Accord européen relatif au transport international des marchandises Dangereuses par Route. wiązany jest wytwarzać odpady zgodnie z posiadaną decyzją. Zmiana klasyfikacji, a w konsekwencji zmiana kodu wytwarzanego odpadu może zaowocować obowiązkiem wystąpienia o zmianę pozwolenia zintegrowanego - np. w zakresie sposobu i miejsca gromadzenia odpadów przewidzianych do wytwarzania zastąpienie kodu 190112 kodem 1901 11* wraz z określeniem postępowania $\mathrm{z}$ odpadami niebezpiecznymi, rodzaju i ilości odpadów dopuszczonych do wytwarzania w ciągu roku, ilości odpadów poddawanych przetworzeniu w instalacji i ilości odpadów powstających w wyniku przetworzenia, rodzaju i ilości odpadów poddawanych stabilizacji, rodzajów i ilości odpadów poddanych przetworzeniu w instalacji i powstających w wyniku przetworzenia.

Konsekwencje uznania danego odpadu, jako odpadu niebezpiecznego:

- obowiązek kontroli tych odpadów rozumiany jako śledzenie ich użycia od wytworzenia do 
końcowego zagospodarowania (art. 17 Dyrektywy odpadowej) ${ }^{13}$,

- zakaz mieszania odpadów niebezpiecznych (art. 18 Dyrektywy odpadowej),

- obowiązek odpowiedniego pakowania i ostrzegania o właściwościach niebezpiecznych (art. 19 Dyrektywy odpadowej oraz Kodeks pracy dział X),

- szczelny system zezwoleń na działania związane z gospodarką odpadami (art. 23-25 Dyrektywy odpadowej),

- bardziej rygorystyczny system dopuszczenia do składowania (dyrektywa składowiskowa) ${ }^{14}$.

Rozważając sposób postępowania z odpadami niebezpiecznymi, należy przeanalizować również to, jakiego rodzaju działania podejmować przed zmianą pozwolenia zintegrowanego, jednocześnie mając już wiedzę co do tego, że określony rodzaj odpadu klasyfikować należy jako niebezpieczny (w okresie przejściowym pomiędzy uzyskaniem wyników badań w związku z charakterystyką odpadu a zmianą pozwolenia zintegrowanego). Ponieważ przepisy nie przewidują procedury zmiany kodu odpadu, uznać należy, że w przypadku uzyskania danych co do konieczności zmiany klasyfikacji odpadów - na skutek przeprowadzonych badań - zmienić należy sposób postępowania z nimi, jednocześnie występując o zmianę pozwolenia zintegrowanego. Nie należy przy tym naruszać pozwolenia zintegrowanego. Wniosek o zmianę pozwolenia zintegrowanego powinien być złożony nawet przed faktycznym wytworzeniem odpadów niebezpiecznych, tak by w momencie uznania danego odpadu za niebezpieczny dopuszczalny był określony rodzaj postępowania. Procedurę zamiany pozwolenia zintegrowanego określa art. 214 i n. p.o.ś. Przy tym, na wstępnym etapie, wystarczające jest poinformowanie organu administracji o zmianach związanych z funkcjonowaniem instalacji (wytwarzaniem odpadów niebezpiecznych), wówczas to organ będzie decydował

13 Dyrektywa Parlamentu Europejskiego i Rady 2008/98/WE z dnia 19 listopada 2008 r. w sprawie odpadów oraz uchylająca niektóre dyrektywy, Dz.Urz. UE L 312/3.

14 Dyrektywa Rady 1999/31/WE z dnia 26 kwietnia 1999 r. w sprawie składowania odpadów, Dz.Urz. WE L 182 z 16.07.1999, s. 1, z późn. zm. o tym, czy należy dokonać zmiany pozwolenia zintegrowanego (art. 214 ust. 2 p.o.ś.). ${ }^{15}$

Pamiętać przy tym należy o konieczności zapewnienia odpowiednich warunków ewentualnego składowania odpadów niebezpiecznych. Na składowisku odpadów niebezpiecznych nie mogą być składowane odpady inne niż niebezpieczne. Natomiast stałe odpady niebezpieczne mogą być składowane w wydzielonych częściach składowiska odpadów innych niż niebezpieczne i obojętne, pod warunkiem że ta wydzielona część będzie spełniać wymagania określone dla składowisk odpadów niebezpiecznych. W takich wydzielonych częściach nie mogą być składowane odpady inne niż niebezpieczne (art. 106 i 107 u.o.).

Wymogi prawne dla poszczególnych typów składowisk określają przepisy Rozporządzenia Ministra Środowiska z dnia 30 kwietnia 2013 r. w sprawie składowisk odpadów ${ }^{16}$ oraz dyrektywa składowiskowa.

\section{3. Żużle i popioly produktami ubocznymi}

Uznając, że w toku prac instalacji powstaje odpad niebezpieczny, można poddać analizie prawne uwarunkowania zmiany statusu odpadu na produkt uboczny.

Zgodnie ze znowelizowanym art. 11 ust. 4-4f u.o. uznanie albo odmowa uznania przedmiotu lub substancji za produkt uboczny następuje $\mathrm{w}$ drodze decyzji marszałka województwa wydawanej po zasięgnięciu opinii wojewódzkiego inspektora ochrony środowiska właściwego ze względu na miejsce wytwarzania tego przedmiotu lub tej substancji. Decyzję o uznaniu przedmiotu lub substancji za produkt uboczny wydaje się na czas oznaczony, nie dłuższy niż 10 lat. Przed wydaniem opinii, o której mowa w ust. 4, wojewódzki inspektor ochrony środowiska może przeprowadzić kontrolę w zakresie objętym zgłoszeniem, o którym mowa w ust. 2 . W kontroli, o której mowa w ust. 4 b, może uczestniczyć marszałek województwa. W przypadku negatywnej opinii wojewódzkiego inspektora ochrony środowiska marszałek województwa wydaje decyzję o odmowie uznania przedmiotu lub substancji za produkt uboczny. W przypadku doko-

15 Ustawa z dnia 27 kwietnia 2001 r. Prawo ochrony środowiska, t.j. Dz.U. 2018, poz. 799 (dalej: p.o.ś.).

16 Rozporządzenia Ministra Środowiska z dnia 30 kwietnia 2013 r. w sprawie składowisk odpadów, Dz.U. 2013, poz. 523. 
nywania zmian w procesie produkcyjnym, w którym powstają przedmiot lub substancja uznane za produkt uboczny, lub w procesie, w którym są one wykorzystywane, wytwórca przedmiotu lub substancji jest obowiązany do dokonania nowego zgłoszenia uznania przedmiotu lub substancji za produkt uboczny ${ }^{17}$. Minister właściwy do spraw środowiska może określić, w drodze rozporządzenia, szczegółowe kryteria dotyczące uznania przedmiotu lub substancji za produkt uboczny, kierując się względami ochrony środowiska, życia lub zdrowia ludzi. Jak na razie brak stosownego rozporządzenia.

Wyjaśnić należy, że produkt uboczny nie jest odpadem. Zarówno odpad, jak i produkt uboczny są przedmiotem lub substancją. Odpad może być pozostałością procesu produkcyjnego (ale nie tylko), a produkt uboczny zawsze jest pozostałością procesu produkcji, której celem nie jest jego produkcja. Ustawodawca, mając na uwadze przede wszystkim ostrożne obchodzenie się z pozostałościami poprodukcyjnymi, ochroną środowiska, życia i zdrowia ludzi, nie zezwala na swobodne dysponowanie pozostałościami poprodukcyjnymi. Zasadniczo traktuje je jako odpady. Z uwagi jednak na fakt, że pozostałości poprodukcyjne mogą być bez szkody dla chronionych wartości środowiskowych i zdrowotnych ponownie wykorzystane, ustawodawca dopuścił w ściśle określonych wypadkach uznanie ich nie za odpad, ale za produkt uboczny. To na zgłaszającym ciąży obowiązek prawidłowego sporządzenia zgłoszenia i wykazania zasadności swoich twierdzeń, tj. obalenia domniemania uznania danego produktu lub substancji będącej pozostałością procesu produkcyjnego, którego celem nie było powstanie tego produktu lub substancji, za odpad i uznania go za produkt uboczny ${ }^{18}$.

Pojęcie produktu ubocznego jest relatywnie nowe dla polskiego prawa, stąd też występować mogą trudności przy stosowaniu przepisów go dotyczących. Problemy takie mogą występować na poziomie weryfikowania kumulatywnego spełnienia warunków prze-

17 Ustawa z dnia 20 lipca 2018 r. o zmianie ustawy - Prawo ochrony środowiska oraz ustawy o odpadach, Dz.U. 2018, poz. 1564.

18 Por. Wyrok WSA w Poznaniu z dnia 28 czerwca 2016 r., sygn. II SA/Po 1087/15 (dalej: CBOSA). widzianych w u.o. oraz stosowania przepisów dotyczących postępowania administracyjnego w zakresie nadania przedmiotowi lub substancji statusu produktu ubocznego. Sprawdzenie wypełnienia kryteriów opisanych u.o. jest o tyle trudne, że w większości przypadków wymaga pogłębionej analizy abstrakcyjne zrekonstruowanego procesu produkcyjnego, którego wynikiem ma być produkt uboczny. Możliwość stwierdzenia integralności procesu produkcyjnego, w którym powstaje dana substancja, względem całości zachodzących procesów produkcyjnych może wymagać niejednokrotnie specjalistycznej wiedzy technicznej, zwłaszcza wobec zaniku konieczności występowania bezwzględnych powiązań substancji z miejscem wytwarzania i przetwarzania, co spowodowane jest zwiększającym się wyspecjalizowaniem zakładów produkcyjnych. Wymaga ona zatem wnikliwej analizy konkretnego przypadku, co spoczywa na organach administracji.

W ustawie o odpadach znajduje się definicja odpadu i produktu ubocznego. Zgodnie z art. 3 pkt 6 u.o. odpad - to każda substancja lub przedmiot, których posiadacz pozbywa się, zamierza się pozbyć lub do których pozbycia się jest obowiązany. ${ }^{19}$

Kluczowym elementem tej definicji „odpadów” jest określenie „usuwa” (pozbywa się). Takie sformułowanie oznacza, że wspólnotowa regulacja prawna dotycząca gospodarki odpadami posługuje się pojęciem „odpadów” w znaczeniu subiektywnym. Skoro „odpadem” jest każda substancja lub przedmiot, jeżeli ich posiadacz „usuwa je, zamierza je usunąć lub do ich usunięcia był zobowiązany".

W konsekwencji rozstrzygnięcie o tym, czy w konkretnym przypadku winny mieć zastosowanie przepisy Ustawy o odpadach zależne jest od tego, „czy zasadnie można twierdzić, że ich posiadacz usuwa tą substancję lub produkt, zamierza ją usunąć lub jest zobowiązany ją usunąć"20.

Koncentrując się na istotnej dla sprawy pozostałości procesu produkcyjnego, uznać należy, że cechą zasadniczą pozwalającą na odróżnienie odpadu od produktu ubocznego jest pozbycie się ich. Odpad

19 T.j. Dz.U. 2018, poz. 992.

20 A. Wasilewski, Podstawowe zasady gospodarki odpadami, „Europejski Przegląd Sądowy”, 2008, t. 8, s. 4-13. 
jest bowiem przedmiotem lub substancją, którego/ której posiadacz się pozbywa, zamierza się pozbyć lub, do którego/której pozbycia się jest zobowiązany. Natomiast produkt uboczny jest przedmiotem lub substancją, którego dalsze wykorzystanie jest pewne.

W wyroku z dnia 18 grudnia 2007 r. Trybunat ${ }^{21}$ przyjął, że „zakwalifikowanie substancji lub przedmiotu jako odpadu w rozumieniu art. 1 lit. a Dyrektywy wynika przede wszystkim z zachowania posiadacza tych produktów oraz rozumienia pojęcia «usuwa». W uzasadnieniu wskazano, że państwa członkowskie mogą określać różne kategorie odpadów, lecz obowiązki ich interpretacji wynikają z dyrektywy lub innych przepisów wspólnotowych. W innym orzeczeniu z dnia 15 stycznia 2004 r. w sprawie C-235/02 przyjęto, że zakres pojęcia „odpad” zależy od znaczenia terminu „pozbycie” z art. 1a cyt. Dyrektywy ${ }^{22}$.

Jednakże samo subiektywne odczucie wytwórcy odpadu, że to, co wytworzył, odpadem nie jest - bowiem nie zamierza się tego pozbywać, tylko pragnie to wykorzystać - nie świadczy jeszcze o tym, że nie mamy do czynienia $\mathrm{z}$ odpadem. W toku postępowania zmierzającego do nadania odpadowi statusu produktu ubocznego istotne są dowody świadczące o możliwości wykorzystania danej substancji jako produktu ubocznego. Dowodami tymi mogą być w szczególności umowy potwierdzające wykorzystanie przedmiotu lub substancji do określonych celów lub potwierdzające właściwości przedmiotu bądź substancji wyniki badań, wykonanych przez laboratoria, o których mowa w art. 147a p.o.s. ${ }^{23}$

Zgodnie z treścią art. 10 u.o. przedmiot lub substancja powstające $\mathrm{w}$ wyniku procesu produkcyjnego, którego podstawowym celem nie jest ich produkcja, mogą być uznane za produkt uboczny, niebędący odpadem, jeżeli są łącznie spełnione następujące warunki:

- dalsze wykorzystywanie przedmiotu lub substancji jest pewne;

21 Wyrok TSUE z dnia 18 grudnia 2007 r., sprawa C-194/05, Komisja Wspólnot Europejskich przeciwko Republice Włoskiej, Dz.U. C 182 z 23.7.2005.

22 Wyrok TSUE z dnia 15 stycznia 2004 r., sprawa C-235/2, Criminal proceedings against Marco Antonio Saetti and Andrea Frediani, ECLI:EU:C:2004:26.

23 Por. wyr. WSA w Poznaniu z dnia 13.07.2017 r., sygn. IV SA/ Po 374/17, dostępny na: CBOSA.
- przedmiot lub substancja mogą być wykorzystywane bezpośrednio bez dalszego przetwarzania, innego niż normalna praktyka przemysłowa;

- dany przedmiot lub substancja są produkowane jako integralna część procesu produkcyjnego;

- dana substancja lub przedmiot spełniają wszystkie istotne wymagania, $\mathrm{w}$ tym prawne, $\mathrm{w}$ zakresie produktu, ochrony środowiska oraz życia i zdrowia ludzi, dla określonego wykorzystania tych substancji lub przedmiotów i wykorzystanie takie nie doprowadzi do ogólnych negatywnych oddziaływań na środowisko, życie lub zdrowie ludzi.

W dniu 21 lutego 2007 r. Komisja Rady i Parlamentu Europejskiego wydała Komunikat dotyczący odpadów i produktów ubocznych ${ }^{24}$. Celem Komunikatu jest wyjaśnienie definicji odpadu oraz powstałej w praktyce gospodarczej kwestii - czy i w jakich przypadkach substancje niestanowiące podstawowego celu procesu technologicznego (a więc w zasadzie mogące być uznane za odpad produkcyjny) mogą być potraktowane jako niespełniające przesłanek odpadu, a w konsekwencji wyłączone z reżimu odpadowego.

Wprawdzie Komunikat nie jest obowiązującym aktem prawa unijnego, ale stanowi istotną wskazówkę dla podmiotów gospodarczych i właściwych organów dokonujących klasyfikacji danych substancji pozostałych z procesu produkcji. Wskazówki Komunikatu uwzględniają dotychczasowe orzecznictwo Trybunału Sprawiedliwości ${ }^{25}$. W Komunikacie skonstruowano test, który musi przejść materiał będący pozostałością procesu produkcyjnego, by można go było uznać za produkt uboczny. Zgodnie z Komunikatem substancja powstająca w wyniku procesu technologicznego, którego podstawowym celem nie jest jej wyprodukowanie, może być uznana za produkt uboczny, a nie za odpad, w przypadku gdy dalsze wykorzystanie substancji:

- jest pewne,

- substancja może być wykorzystana bezpośrednio bez jakiegokolwiek przetwarzania innego niż normalna praktyka przemysłowa,

24 Komunikat Komisji Rady I Parlamentu Europejskiego w sprawie Komunikat wyjaśniający dotyczący odpadów i produktów ubocznych, Bruksela, dnia 21.2.2007 r., $\operatorname{KOM(2007)} 59$.

25 Por. Wyrok WSA w Rzeszowie z dnia 28 kwietnia 2015 r., sygn. II SA/Rz 1415/14, dostępny na: CBOSA. 
- jest produkowana jako integralna część procesu produkcyjnego,

- dalsze wykorzystanie jest zgodne z prawem, tzn. dana substancja spełnia wymagania w zakresie ochrony środowiska, zdrowia i życia ludzkiego i nie doprowadzi do niekorzystnego oddziaływania na środowisko.

Wszystkie cztery przesłanki według Komunikatu muszą być spełnione łącznie.

Odnosząc się do pierwszej przesłanki (określonej zarówno w Ustawie o odpadach, jak i Komunikacie), wyjaśnić należy, że jeśli istnieje prawdopodobieństwo, że materiał faktycznie nie nadaje się do wykorzystania, nie spełnia kryteriów technicznych koniecznych do jego wykorzystania lub nie istnieje rynek na ten materiał, nadal należy uznawać produkt za odpad. Natomiast pewność wykorzystania danego materiału oznacza, że może on stanowić produkt uboczny. Dotyczy to na przykład istnienia długoterminowych umów pomiędzy posiadaczem odpadów i jego dalszymi użytkownikami, wykorzystującymi ten materiał do określonych celów. Również w sytuacji, gdy istnieje możliwość odsprzedaży danego materiału z zyskiem przez producenta, może to wskazywać na prawdopodobieństwo, że materiał ten zostanie wykorzystany. Wysoka cena, zgodna z bieżącymi cenami rynkowymi lub je przewyższająca, może wskazywać na fakt, że materiał nie jest odpadem. Jednakże gdy materiał ma być składowany bezterminowo, przed potencjalnym, lecz niepewnym ponownym wykorzystaniem na okres jego składowania należy uznać go za odpad ${ }^{26}$.

Dalej należy ustalić, czy materiał nadaje się do ponownego wykorzystania bez konieczności dalszego przetwarzania. W niektórych przypadkach stosowanie tego testu może okazać się trudne, gdyż często w ramach łańcucha wartości produktu ubocznego istnieje pewien łańcuch zadań, które należy podjąć $\mathrm{w}$ ramach dalszego wykorzystania materiału: materiał zostaje wytworzony, następnie może być myty, suszony, rafinowany lub homogenizowany, może być uzupełniany o pewne właściwości lub inne materiały konieczne do dalszego wykorzystania, jego jakość

26 Por. Wyrok TSUE z dnia 18.04.2002 r., sprawa C-9/00, Palin Granit Oy and Vehmassalon kansanterveystyön kuntayhtymän hallitus, ECLI:EU:C:2002:232. może podlegać kontroli itd. Niektóre z tych zadań są realizowane w obiekcie produkcyjnym wytwórcy, niektóre u kolejnego użytkownika, a jeszcze inne przez pośrednika. O ile zadania te stanowią integralną część procesu produkcyjnego, należy uznać materiał za produkt uboczny ${ }^{27}$. Do tego rodzaju działań nie można zaliczyć np. niedozwolonego rozcieńczania odpadów niebezpiecznych, co miałoby prowadzić do „rozmycia” szkodliwych właściwości chemicznych odpadu ${ }^{28}$. Sam proces przetworzenia odpadów może być również problematyczny, czego przykładem może być przetworzenie popiołów w materiał służący do budowy dróg i nasypów (tzw. BASUTAB), gdzie proces przetworzenia polega na dodaniu piachu, co z kolei nie oznacza, że może być on wykonywany w każdym miejscu bez odpowiednich zezwoleń. Konieczne jest przy tym zachowanie określonych wymogów pozwalających na mieszanie odpadów niebezpiecznych z innymi substancjami ${ }^{29}$.

Jeśli materiał został przygotowany do dalszego wykorzystania jako integralny element ciągłego procesu produkcyjnego i następnie ulega przekazaniu do dalszego wykorzystania, w takiej sytuacji stanowi on produkt uboczny.

W takim wypadku należy ocenić, czy zadania opisane w poprzedniej części stanowią integralną część ciągłego procesu produkcyjnego, biorąc pod uwagę stopień przydatności materiału do dalszego wykorzystania, naturę i zakres zadań niezbędnych do przygotowania materiału przed dalszym wykorzystaniem, integracji tych zadań w ramach głównego procesu produkcyjnego oraz określając czy zadania wykonywane przez podmiot inny niż producent mogą się do niego odnosić.

27 Por. Wyrok ETS z dnia 11.11.2003 r., sprawa C-114/01, AvestaPolarit Chrome Oy, ECLI:EU:C:2003:448; Wyrok TSUE z dnia 11.11.2004 r. w sprawie C-457/02, postępowanie karne przeciwko A. Nissellemu, ECLI:EU:C:2004:707, tak samo orzeczenie ETS z dnia 01.03.2007 r., w sprawie C-176/05, KVZ retec HmbH przeciwko Republice Austrii, ECLI:EU:C:2007:123.

28 K. Gaska, J.W. Wandrasz, Wykorzystanie sieci neuronowych w programowaniu gospodarki odpadami (w:) Techniczne, ekonomiczne i organizacyjne aspekty gospodarki odpadami, Gniezno-Poznań 2003, s. 67.

29 W. Dżygóra, Wpływ kadmu na organizm człowieka (w:) T. Bugaj (red.), Ekologia środowiska a zdrowie, Jelenia Góra 1996 , s. 40 i n. 
Jeśli materiał opuszcza obiekt lub fabrykę, w której został wytworzony, w celu dalszego przetworzenia, może to stanowić dowód, że zadania tego rodzaju już nie są częścią tego samego procesu produkcyjnego. Jeśli materiał jest niezbędnym elementem podstawowej działalności producenta, stanowi to dowód, że nie jest on odpadem.

Podkreślić należy, że jeżeli dalsze wykorzystanie produktu wymaga zastosowania dodatkowego procesu odzyskiwania, nawet jeśli dalsze wykorzystanie jest pewne, w świetle orzecznictwa ETS stanowi to dowód, że materiał ten jest odpadem do momentu ostatecznego zakończenia tego procesu.

Najwięcej wątpliwości budzi czwarta przesłanka wymieniona w art. 10 u.o., stwarza ona bowiem największą swobodę interpretacyjną dla podmiotów stosujących prawo. Zastosowanie niedookreślonych zwrotów, takich jak konieczność wskazania, że dana substancja lub przedmiot „spełniają wszystkie istotne wymagania, w tym prawne, w zakresie produktu, ochrony środowiska oraz życia i zdrowia ludzi, dla określonego wykorzystania tych substancji" oraz że ich wykorzystanie „nie doprowadzi do ogólnych negatywnych oddziaływań na środowisko i zdrowie ludzi”, pozostawia znaczną swobodę interpretacyjną w rękach organów administracji publicznej. Swoboda ta jest ograniczona jedynie przez wymóg stosownego, szczegółowego uzasadnienia.

Najjaśniejszym kryterium wymagającym spełnienia jest zgodność $\mathrm{z}$ wymogami prawa. Ilekroć zatem na posiadaczu substancji lub przedmiotu będzie spoczywał obowiązek postąpienia z nimi jak z odpadem (na przykład unieszkodliwienie lub poddanie procesowi odzysku przy użyciu określonych metod), można stwierdzić, że mamy do czynienia z odpadem. A contrario, jeśli na posiadaczu nie ciąży obowiązek prawny powzięcia konkretnych czynności wobec pozostałości procesu produkcyjnego, nadanie statusu produktu ubocznego jest zgodne $\mathrm{z}$ prawem.

Kolejną przesłanką jest wykorzystanie w zakresie produktu, ochrony środowiska oraz życia i zdrowia ludzi. Oceniając, czy jest ona spełniona w części dotyczącej wykorzystania w zakresie produktu, należy zwrócić uwagę na zgodność specyfikacji substancji stanowiącej pozostałość procesu produkcyjnego ze specyfikacjami technicznymi substancji podobnych, które występują na rynku. O spełnieniu tej przesłanki w zakresie ochrony środowiska oraz życia i zdrowia ludzi może również świadczyć czynienie zadość wymaganiom określonym Ustawą o ogólnym bezpieczeństwie produktu. Przy braku odpowiednich specyfikacji można uznać, że parametry techniczne substancji lub przedmiotu są właściwe.

Sformułowanie „nie doprowadzi do ogólnych negatywnych oddziaływań na środowisko i zdrowie ludzi" uprawnia do wysunięcia tezy o konieczności dokonania każdorazowo bilansu korzyści i zagrożeń płynących z zaklasyfikowania pozostałości procesu produkcyjnego jako odpadu lub produktu ubocznego. Zdarzyć się może bowiem, że substancja lub przedmiot będą przynosiły większą korzyść pod względem ekonomii środowiskowej również przez fakt niewywoływania negatywnych skutków oddziaływania na środowisko po nadaniu jej statusu odpadu.

Uboczne produkty spalania mogą być wykorzystane w produkcji cementu, stabilizacji gruntów, podbudowy dróg czy rekultywacji terenów po wyrobiskach. Odpad o kodzie 190112 mógłby być uznany za produkt uboczny przy spełnieniu warunków określonych w Ustawie o odpadach, jeśli jednak będzie on spełniał właściwości pozwalające scharakteryzować go jako odpad niebezpieczny (odpad $\mathrm{z}$ „”), wówczas utrudnione będzie zakwalifikowanie go jako produktu ubocznego - chociaż brak przepisów wprost zakazujących uznania odpadów niebezpiecznych za produkty uboczne, istotny może być tutaj stopień „zanieczyszczenia” substancjami szkodliwymi. Przy zakazie rozcieńczania substancji szkodliwych pojawia się oczywiście problem użytkowania odpadów mogących wywoływać negatywne skutki dla środowiska. Wykorzystanie tego rodzaju odpadu (produktu ubocznego) może bowiem doprowadzić do ogólnych negatywnych oddziaływań na środowisko, życie lub zdrowie ludzi. Należy również wskazać, że celem nowelizacji z dnia 20 lipca 2018 r. o zmianie Ustawy - Prawo ochrony środowiska oraz Ustawy o odpadach, było ograniczenie możliwości zamiany statusu odpadów niebezpiecznych na produkty uboczne, co potwierdza uzasadnienie projektu wyżej wymienionej ustawy o zmianie Ustawy o odpadach. W uzasadnieniu do projektu ustawy podkreśla się, iż obecnie obowiązująca w tej materii procedura (która do tej pory polegała na 
zgłoszeniu i braku wyrażenia przez marszałka sprzeciwu) „(..) prowadzić może (...) do sytuacji, gdy za produkt uboczny uznane zostają odpady niebezpieczne, których przetwarzanie powinno być prowadzone z zachowaniem szczególnej ostrożności i z zachowaniem przepisów gospodarki odpadami przez podmioty niemożliwe, ale niewątpliwie znacznie utrudnione będzie w takim przypadku uzyskanie zgody właściwego organu administracji publicznej.

Powyżej opisane uwarunkowania mają charakter niedookreślony (w pewien sposób otwarty), ale muszą być uwzględnione przy ewentualnych działaniach zamie-

\section{Odpad o kodzie 190112 mógłby być uznany} za produkt uboczny przy spełnieniu warunków określonych w Ustawie o odpadach, jeśli jednak będzie on spełniał właściwości pozwalające scharakteryzować go jako odpad niebezpieczny (odpad z ” "), wówczas utrudnione będzie zakwalifikowanie go jako produktu ubocznego - chociaż brak przepisów wprost zakazujących uznania odpadów niebezpiecznych za produkty uboczne, istotny może być tutaj stopień „zanieczyszczenia” substancjami szkodliwymi.

uprawnione i w przystosowanych do tego instalacjach. Natomiast w konsekwencji uznania takich odpadów niebezpiecznych za produkt uboczny, w drodze milczącej zgody marszałka, odpady niebezpieczne mogą być dalej przetwarzane bez zastosowania wymogów ochrony środowiska, powodując zagrożenia dla zdrowia i życia obywateli lub dla środowiska"30. W opinii projektodawców przedmiotowa nowelizacja przepisów Ustawy o odpadach pozwoli wyeliminować wskazane powyżej ryzyko ${ }^{31}$. Przekształcenie odpadów niebezpiecznych w produkty uboczne nie jest co do zasady

30 Opinia do ustawy o zmianie ustawy - Prawo ochrony środowiska oraz ustawy o odpadach (druk nr 875) z dnia 21 czerwca 2018 r., https://www.senat.gov.pl/gfx/senat/pl/senatekspertyzy/4737/plik/875o.pdf (dostęp 13.11.2019).

31 Tamże. rzających do przekwalifikowania odpadu na produkt uboczny. Należy wskazać, że przytaczany Komunikat Komisji traktuje „żużel i pył z produkcji żelaza i stali” oraz „produkty uboczne z procesów spalania - gips z odsiarczania gazów spalinowych” jako produkty uboczne $^{32}$. Jednocześnie dla odniesienia się do zindywidualizowanego przypadku niezbędne jest uzyskanie informacji technicznych i technologicznych. Wskazać również należy na Rozporządzenie (We) nr 1907/2006 Parlamentu Europejskiego i Rady z dnia 18 grudnia 2006 r. w sprawie rejestracji, oceny, udzielania zezwoleń i stosowanych ograniczeń w zakresie chemikaliów $(\mathrm{REACH})$ i utworzenia Europejskiej Agencji Chemika-

32 Komunikat Komisji Rady i Parlamentu Europejskiego w sprawie Komunikat wyjaśniający dotyczący odpadów i produktów ubocznych..., dz. cyt., s. 13 i 14 
liów, zmieniające Dyrektywę 1999/45/WE oraz uchylające Rozporządzenie Rady (EWG) nr 793/93 i Rozporządzenie Komisji (WE) nr 1488/94, jak również Dyrektywę Rady 76/769/EWG i Dyrektywy Komisji 91/155/EWG, 93/67/EWG, 93/105/WE i 2000/21/WE (Dz.U. L 396 z 30.12.2006), które reguluje kwestię stoso-
Zaryzykować można twierdzenie, że zmiany regulacji prawnych wprowadzające wymóg uzyskania decyzji przy uznaniu odpadu za produkt uboczny będą miały skutek zupełnie odwrotny od zakładanego. Wytwórcy odpadów, działający zgodnie z prawem, będą musieli przejść dłuższą i bardziej skomplikowaną drogę do

\section{Zaryzykować można twierdzenie, że zmiany regulacji prawnych wprowadzające wymóg uzyskania decyzji przy uznaniu odpadu za produkt uboczny będą miały skutek zupełnie odwrotny od zakładanego.}

wania chemikaliów oraz wydawania zezwoleń i wprowadzania ograniczeń ich obrotu. Na koniec zaznaczyć można, że ostatnia nowelizacja dyrektywy odpadowej kładzie nacisk na poszerzenie zastosowania instytucji produktów ubocznych jako istotnego elementu gospodarki odpadami w obiegu zamkniętym ${ }^{33}$.

\section{Wnioski}

Opisane regulacje prawne prowadzą do sytuacji, w której te same odpady (popiół i żużel) na skutek zmiany metodyki przeprowadzenia badań - spowodowanej wejściem w życie nowych regulacji prawnych - mogą uzyskać status odpadów niebezpiecznych, pomimo tego, że nic nie zmieni się w procesie ich wytworzenia. Jednocześnie wytwórca odpadów sam będzie podejmował decyzję, co do tego, czy określone kategorie odpadów traktować jako odpad niebezpieczny, co jest konsekwencją występowania popiołów i żużli jako odpadów „lustrzanych”. Uznanie popiołów i żużli za odpady niebezpieczne powoduje również znaczne komplikacje, jeśli chodzi o możliwość uznania ich za produkty uboczne - pomimo tego, że potencjalnie istnieje rynek zbytu dla tego typu substancji i jest możliwość wykorzystania ich w procesie budowlanym.

33 Dyrektywa Parlamentu Europejskiego i Rady (UE) 2018/851 z dnia 30 maja 2018 r. zmieniająca dyrektywę 2008/98/WE w sprawie odpadów, Dz.Urz. UE L 150/109. uznania odpadu za produkt uboczny (wydaje się to wręcz sprzeczne z ideą gospodarki odpadami w obiegu zamkniętym). Z kolei podmioty, które chcą nielegalnie wykorzystywać odpady do produkcji, w żaden sposób nie zostają zachęcone do uprawomocnienia podejmowanych przez siebie działań.

\section{Bibliografia}

Dżygóra W., Wpływ kadmu na organizm człowieka (w:) T. Bugaj (red.), Ekologia środowiska a zdrowie, Jelenia Góra 1996.

Gaska K., Wandrasz J.W., Wykorzystanie sieci neuronowych w programowaniu gospodarki odpadami (w:) Techniczne, ekonomiczne i organizacyjne aspekty gospodarki odpadami, Gniezno-Poznań 2003.

Korzeniowski P., Instrumenty prawne reglamentacji $w$ gospodarce odpadami, „Przegląd Prawa Ochrony Środowiska” 2014, t. 3. Korzeniowski P., Model prawny systemu gospodarki odpadami. Studium administracyjno-prawne, Łódź 2014.

Wasilewski A., Podstawowe zasady gospodarki odpadami, „Europejski Przegląd Sądowy” 2008, t. 8.

\section{Akty prawne}

Dyrektywa Parlamentu Europejskiego i Rady (UE) 2018/851 z dnia 30 maja 2018 r. zmieniająca dyrektywę 2008/98/WE w sprawie odpadów, Dz.Urz. UE L 150/109.

Dyrektywa Parlamentu Europejskiego i Rady 2008/98/WE z dnia 19 listopada 2008 r. w sprawie odpadów oraz uchylająca niektóre dyrektywy, Dz.Urz. UE L 312/3. 
Dyrektywa Rady 1999/31/WE z dnia 26 kwietnia 1999 r. w sprawie składowania odpadów, Dz.Urz. WE L 182 z 16.07.1999, s. $1, \mathrm{z}$ późn. $\mathrm{zm}$.

Rozporządzenia Ministra Środowiska z dnia 30 kwietnia 2013 r. w sprawie składowisk odpadów, Dz.U. 2013, poz. 523.

Rozporządzenie Komisji (UE) nr 1357/2014 z dnia 18 grudnia 2014 r. zastępujące załącznik III do dyrektywy Parlamentu Europejskiego i Rady 2008/98/WE w sprawie odpadów oraz uchylającej niektóre dyrektywy, Dz.Urz. UE L 365 z 19.12.2014, s. $89, \mathrm{z}$ późn. $\mathrm{zm}$.

Rozporządzenie Ministra Środowiska z dnia 9 grudnia 2014 r. w sprawie katalogu odpadów, Dz.U. 2014, poz. 1923.

Rozporządzenie Rady (UE) 2017/997 z dnia 8 czerwca 2017 r. zmieniające załącznik III do dyrektywy Parlamentu Europejskiego i Rady 2008/98/WE w odniesieniu do niebezpiecznej właściwości HP 14 „Ekotoksyczne”, Dz.Urz. UE L 150 z 14.06.2017, s. 1 .

Ustawa z dnia 14 grudnia 2012 r. o odpadach, t.j. Dz.U. 2018, poz. 992.

Ustawa z dnia 20 lipca 2018 r. o zmianie ustawy - Prawo ochrony środowiska oraz ustawy o odpadach, Dz.U. 2018, poz. 1564.

Ustawa z dnia 24 listopada 2017 r. o zmianie ustawy o odpadach oraz niektórych innych ustaw, Dz.U. 2017, poz. 2422.

Ustawa z dnia 27 kwietnia 2001 r. Prawo ochrony środowiska, t.j. Dz.U. 2018, poz. 799.

\section{Orzecznictwo TSUE}

Wyrok ETS z dnia 01.03.2007 r., w sprawie C-176/05, KVZ retec HmbH przeciwko Republice Austrii, ECLI:EU:C:2007:123.

Wyrok ETS z dnia 11.11.2003 r., sprawa C-114/01, AvestaPolarit Chrome Oy, ECLI:EU:C:2003:448; Wyrok TSUE z dnia 11.11.2004 r. w sprawie C-457/02, postępowanie karne przeciwko A. Nissellemu, ECLI:EU:C:2004:707.

Wyrok TSUE z dnia 15 stycznia 2004 r., sprawa C-235/2, Criminal proceedings against Marco Antonio Saetti and Andrea Frediani, ECLI:EU:C:2004:26.
Wyrok TSUE z dnia 18 grudnia 2007 r., sprawa C-194/05, Komisja Wspólnot Europejskich przeciwko Republice Włoskiej, Dz.U. C 182 z 23.7.2005.

Wyrok TSUE z dnia 18.04.2002 r., sprawa C-9/00, Palin Granit Oy and Vehmassalon kansanterveystyön kuntayhtymän hallitus, ECLI:EU:C:2002:232.

\section{Orzecznictwo WSA}

Wyrok WSA w Poznaniu z dnia 28 czerwca 2016 r., sygn. II SA/ Po $1087 / 15$.

Wyrok WSA w Rzeszowie z dnia 28 kwietnia 2015 r., sygn. II SA/ Rz 1415/14

Wyrok WSA w Poznaniu z dnia 13.07.2017 r., sygn. IV SA/Po 374/17.

\section{Pozostate}

Druk nr 2014 z dnia 9 listopada 2017 r. o zmianie ustawy o odpadach z projektami aktów wykonawczych, https://www.sejm. gov.pl/Sejm8.nsf/druk.xsp?nr=2014 (dostęp 13.11.2019).

Informacje Instytucji, Organów i Jednostek Organizacyjnych Unii Europejskiej Komisja Europejska, Zawiadomienie Komisji dotyczące wytycznych technicznych w sprawie klasyfikacji odpadów z dnia 9 kwietnia 2018 r., 2018/C 124/01.

Komunikat Komisji Rady I Parlamentu Europejskiego w sprawie Komunikat wyjaśniający dotyczący odpadów i produktów ubocznych, Bruksela, dnia 21.2.2007, $\operatorname{KOM(2007)~} 59$.

Ministerstwo Środowiska, Stanowisko w sprawie zmiany statusu odpadów niebezpiecznych na odpady inne niż niebezpieczne, 18.06.2013, https://archiwum.mos.gov.pl/g2/big/2013_06/ cc27612a0ab016a2a87112d2b0d5d6d2.pdf (dostęp 27.08.2018). Opinia do ustawy o zmianie ustawy - Prawo ochrony środowiska oraz ustawy o odpadach (druk nr 875) z dnia 21 czerwca 2018 r., https://www.senat.gov.pl/gfx/senat/pl/senatekspertyzy/4737/plik/875o.pdf (dostęp 13.11.2019). 